Pancreatic Tumors 
Monographs in Clinical Cytology

Vol. 26

Series Editor

Philippe Vielh Paris 


\section{Pancreatic Tumors}

Volume Editors

Barbara A. Centeno Tampa, FL

Jasreman Dhillon Tampa, FL

107 figures, 100 in color, and 23 tables, 2020

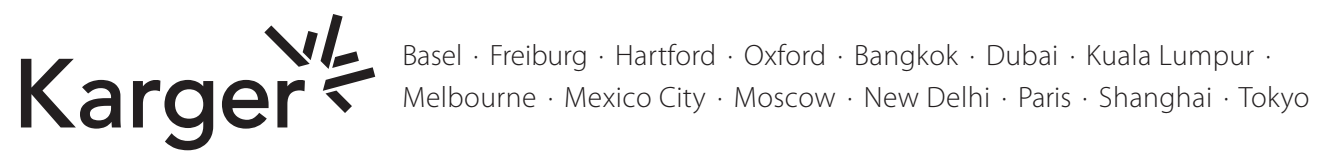


Monographs in Clinical Cytology

Founded 1965 by George L. Wied, Chicago, IL

\author{
Prof. Barbara A. Centeno \\ Department of Pathology \\ Moffitt Cancer Center \\ 12902 USF Magnolia Drive \\ Tampa, FL 33612 (USA) \\ Barbara.Centeno@moffitt.org
}

\author{
Dr. Jasreman Dhillon \\ Associate Member and Associate Professor \\ Department of Pathology \\ Moffitt Cancer Center \\ 12902 USF Magnolia Drive \\ Tampa, FL 33612 (USA) \\ Jasreman.Dhillon@moffitt.org
}

\author{
Library of Congress Cataloging-in-Publication Data \\ Names: Centeno, Barbara A., editor. | Dhillon, Jasreman, editor. \\ Title: Pancreatic tumors / volume editors, Barbara A. Centeno, Jasreman \\ Dhillon. \\ Other titles: Pancreatic tumors (Centeno) | Monographs in clinical \\ cytology ; v. 26. 0077-0809 \\ Description: Basel ; Hartford : Karger, 2020. | Series: Monographs in \\ clinical cytology, 0077-0809; vol. 26 | Includes bibliographical \\ references and indexes. | Summary: "This book provides a comprehensive \\ review of entities that may be encountered in pancreatic cytology. It is \\ designed for cytotechnologists, pathology trainees, pathologists, and \\ cytopathologists. It is also a useful guide for advanced endoscopists \\ performing EUS-guided FNA, and surgeons and oncologists treating \\ patients with pancreatic disease wanting to understand their pathology \\ reports"-- Provided by publisher. \\ Identifiers: LCCN 2020022626 (print) | LCCN 2020022627 (ebook) | ISBN \\ 9783318066036 (hardcover ; alk. paper) | ISBN 9783318066043 (ebook) \\ Subjects: MESH: Pancreatic Neoplasms \\ Classification: LCC RC280.P25 (print) | LCC RC280.P25 (ebook) | NLM W1 \\ MO567KF v.26 2020 | DDC 616.99/437--dc23 \\ LC record available at https://lccn.loc.gov/2020022626 \\ LC ebook record available at https://lccn.loc.gov/2020022627
}

Bibliographic Indices. This publication is listed in bibliographic services, including Current Contents ${ }^{\circledR}$.

Disclaimer. The statements, opinions and data contained in this publication are solely those of the individual authors and contributors and not of the publisher and the editor(s). The appearance of advertisements in the book is not a warranty, endorsement, or approval of the products or services advertised or of their effectiveness, quality or safety. The publisher and the editor(s) disclaim responsibility for any injury to persons or property resulting from any ideas, methods, instructions or products referred to in the content or advertisements.

Drug Dosage. The authors and the publisher have exerted every effort to ensure that drug selection and dosage set forth in this text are in accord with current recommendations and practice at the time of publication. However, in view of ongoing research, changes in government regulations, and the constant flow of information relating to drug therapy and drug reactions, the reader is urged to check the package insert for each drug for any change in indications and dosage and for added warnings and precautions. This is particularly important when the recommended agent is a new and/or infrequently employed drug.

All rights reserved. No part of this publication may be translated into other languages, reproduced or utilized in any form or by any means electronic or mechanical, including photocopying, recording, microcopying, or by any information storage and retrieval system, without permission in writing from the publisher.

(c) Copyright 2020 by S. Karger AG, P.O. Box, CH-4009 Basel (Switzerland)

www.karger.com

Printed on acid-free and non-aging paper (ISO 9706)

ISSN 0077-0809

ISBN 978-3-318-06603-6

e-ISBN 978-3-318-06604-3 


\section{Contents}

Preface

Chapter 1 Introduction to Pancreatic Pathology and Fine-Needle Aspiration Cytology

Dhillon, J. (Tampa, FL)

Chapter 2 Processing of Fine-Needle Aspiration Specimens from Pancreatic Lesions

Dhillon, J. (Tampa, FL)

Chapter 3 Imaging of Pancreatic Tumors

Morse, B.; Klapman, J. (Tampa, FL)

Dhillon, J. (Tampa, FL)

Chapter 5 Non-Neoplastic Masses of the Pancreas

Centeno, B.A. (Tampa, FL); Thomas, S.C. (New York, NY)

Chapter 6

Non-Neoplastic and Neoplastic Cysts of the Pancreas

53

Centeno, B.A. (Tampa, FL); Thomas, S.C. (New York, NY)

Chapter $7 \quad$ Pancreatic Ductal Adenocarcinoma

Betancourt, M. (Jupiter, FL); Dhillon, J. (Tampa, FL)

Chapter 8 Non-Ductal Tumors of the Pancreas

92

Dhillon, J. (Tampa, FL)

Chapter 9 Metastases, Secondary Tumors, and Lymphomas of the Pancreas

Centeno, B.A. (Tampa, FL)

Chapter 10

Mesenchymal Tumors of the Pancreas

Dhillon, J. (Tampa, FL) 